\title{
Effect of Electric Field on the Kinetics of Growth of Lettuce (Lactuca sativa) in a Hydroponic System
}

\author{
Orlando Fuentes-Castañeda1, Martha Lilia Domínguez-Patiño², Jorge Domínguez-Patiño1, \\ Rosa María Melgoza-Alemán ${ }^{2}$, Oscar Gabriel Villegas-Torres ${ }^{3}$ \\ ${ }^{1}$ CIICAp, Universidad Autónoma del Estado de Morelos, Cuernavaca, México \\ ${ }^{2}$ Facultad de Ciencias Químicas e Ingeniería, Universidad Autónoma del Estado de Morelos, Cuernavaca, \\ México \\ ${ }^{3}$ Facultad de Ciencias Agropecuarias, Universidad Autónoma del Estado de Morelos, Cuernavaca, México \\ Email: fuentescasta@yahoo.com
}

Received 28 May 2016; accepted 26 July 2016; published 29 July 2016

Copyright (C) 2016 by authors and Scientific Research Publishing Inc.

This work is licensed under the Creative Commons Attribution International License (CC BY). http://creativecommons.org/licenses/by/4.0/

(c) (i) Open Access

\section{Abstract}

The implementation of alternative harvest systems which are able to accelerate the kinetics of growth of plants, is extremely important to decrease the time of crop. In this sense, Electro-Hydroponic culture, i.e., the application of an electric field in the nutrient solution of the hydroponic culture emerges as an alternative and interesting harvest system. The objective of the present study was to investigate the effect of the electric field applying different intensities of direct current (DC) at the galvanostatic regime $(50,37.5,25$ and $12.5 \mathrm{~mA}$ ) on the growth of lettuce (Lactuca sativa) plants in hydroponic culture. Fifty lettuce plants were used in a nutrient solution, from which 4 groups composed of ten lettuces each one, were subjected at 12.5, 25, 37.5 and $50 \mathrm{~mA}$, respectively. A fifth group of ten lettuces was used as a reference test, i.e., without application of DC. The experiments were carried out during 16 days. The results reveal that the kinetics of growth of the lettuce is dependent on the applied current; actually it is observed an increase in the foliate area of the plants cultivated in the presence of DC than that obtained in the reference test. Furthermore, the plants subjected at $12.5 \mathrm{~mA}$, revealed an increase in the foliate area of $65.3 \%$ and $73.2 \%$ in comparison with the reference test.

\section{Keywords}

Hydroponic, Direct Current, Lettuce, Galvanostatic Regime 


\section{Introduction}

The population's world growth, the decrease of the cultivation lands, as well as the decrease of the water for watering, promote a serious problem in terms of production of foods and famine in some countries of the world. Nowadays, two cultivation forms exist: the traditional cultivation, at open sky and the cultivation in greenhouses. The first is for the sowing of all vegetable products, in greenhouses is related to the cultivation of vegetables like the tomato, lettuce, strawberries, etc.; this type of cultivations are performed without soil (soil-free), the socalled "hydroponic cultivations". The hydroponic cultivations are of bigger productivity and quality than the cultivations done at open sky, due to the fact, that hydroponic cultivation permits a better control in the illnesses derived from the environmental conditions, decreases the harvest-production times and promotes a competitive market condition [1].

The cultivation without soil (soil-free) is the most employed technique is the technique more used to produce vegetables in greenhouse; it requires a continuous supply of nutrients, which is given by means of a nutrient solution (NS) that contains the essential elements for the good development of the cultivations [2]. NS is governed by the laws of the inorganic chemistry; it has reactions that lead to the formation of complexes and to the precipitation of the ions, which avoids that these are available on the roots of the plants [3]. The appropriate $\mathrm{pH}$ of NS for the development of the cultivations is in an established range and it is controlled to neutralize the presence of the bicarbonates in the watering water, because these ions produce high $\mathrm{pH}$, and a high content of them in the radical area provoke the immobilization of $\mathrm{P}, \mathrm{Mn}$ and Fe. In addition, with a high $\mathrm{pH}$ in the NS, Ca and Mg can precipitate with $\mathrm{HPO}_{4}$ [3] and [4]. Among the advantages that present the soilless, it is worth mentioning the next: smaller consumption of water by kilogram of product and bigger production for used surface [5].

Lemström (2008) used an electrostatic generator and applied a voltage gradient of approximately $10 \mathrm{KV} \cdot \mathrm{m}^{-1}$. It was found that the treated plants were greener, more robust and often they showed an important increment in the yield [6]. Bi R. et al., (2010), they investigated the growth of the lettuce in a hydroponic cultivation applying 10 and $50 \mathrm{~Hz}$ of alternating current $\left(10 \mathrm{~Hz} 1 \mathrm{~V} \cdot \mathrm{cm}^{-1} ; 50 \mathrm{~Hz}, 1 \mathrm{~V} \cdot \mathrm{cm}^{-1}\right)$, obtaining yields of $28 \%$ and $106 \%$ respectively compared with the plants that were not subjected to the electric field, the influence of the electric field could last for some time, still after the current has been disconnected, which probably can explain why the plants in the nature are generally green after a day of storm [7]. Myeong et al., (2009) evaluated in the lettuce cultivation the effect of the electric conductivity $\left(0.5,1.0,2.0\right.$ and $\left.3.0 \mathrm{dSm}^{-1}\right)$ revealing the best results at $2.0 \mathrm{dSm}^{-1}$, in terms of: number of leaves, fresh weight and chlorophyll content [8], although according to Mahmoudi et al., (2011) the growth of the lettuce can be affected by a saline stress [9].

The lettuce is par excellence considered the leaf vegetable, given its culinary high quality as fresh salad. It is cultivated in the entire world under different cultivation systems, to sky open and low greenhouse, in soil and in hydroponic [10].

On the basis of the previous statements, the objective of this investigation was to stimulate the growth of the lettuce, using an electrolytic conventional system with two electrodes, at different galvanostatic regimes. The hypothesis was that when applying the electric field in the nutrient solution it is promoted the migration of the cations and anions to the electrodes and at the same time to the root of the plant with different levels of intensity of electric current (DC).

\section{Materials and Methods}

This investigation was carried out in the experimental field of the Faculty of Agricultural Sciences (FCA) of the Autonomous University of Morelos (UAEM), located at $18^{\circ} 58^{\prime} 53^{\prime \prime}$ of north latitude and $99^{\circ} 13^{\prime} 58.4^{\prime \prime}$ of longitude west, to an altitude of $1804 \mathrm{~m}$. The climate is semiwarmsubwet with rains in summer and it presents temperatures between $9^{\circ} \mathrm{C}$ and $32^{\circ} \mathrm{C}$ [11].

\subsection{Materials}

For the germination of the lettuce (Lactuca sativa) seeds, a plastic rigid tray was used with $28 \mathrm{~cm}$ of wide 54.5 $\mathrm{cm}$ of long, $4 \mathrm{~cm}$ of height and 200 square cavities with perforation in the base for drainage. The substrate to germinate the seed was the Mixture Sunshine ${ }^{\circledR}$ mix 3, with the addition of moss of Canadian origin. The mixture was composed of Canadian moss, vermiculite, carbonates to adjust the $\mathrm{pH}$ (5.9 - 6.2), a moistening patented agent and a formulation bases of fertilizers. All the above-mentioned allows the retention of the water and a good aeration, the mixture is innocuous and free of overgrowth seeds, which does not require any fumigation or 
disinfection before its use; the moistening patented agent of Sun Gro Horticulture is not leached, neither it suffers chemical decomposition [12]. The lettuce seed was placed in the cavities of the tray and it was wet with drinkable water of the area. The germination took 3 days, when the plants developed two cotyledons the tray was taken to the greenhouse to provide it of solar light.

On the other hand, several nutritious solutions (NS) were prepared containing $30 \%, 60 \%$ and $80 \%$ of a standard Steiner formulation. These solutions were employed in different stages of the growth of the plants [13]. In the case of the NS at 30\%, the system was watered until having two true leaves, to continue with NS at $60 \%$ up to three true leaves and lastly NS was used at $80 \%$ up to four true leaves (Table 1), the micronutrients concentration was used unchanged according to Table 2 in different stages of the growth of the plants. The total time from the germination until the plant presented four true leaves corresponded to 23 days.

For the growth of the plants, five tubes of polyvinyl chloride (PVC) with $150 \mathrm{~cm}$ of longitude and $10.16 \mathrm{~cm}$ of diameter were implemented as the Electro-hydroponic cell. The cell had five perforations of $4.45 \mathrm{~cm}$ in the superior section, distributed each $25 \mathrm{~cm}$. Reductions of PVC and valves with 1.27 diameter $\mathrm{cm}$ were settled in each end of the tubes for purging the system. Polyethylene sheets were also used with $1.27 \mathrm{~cm}$ of thickness as a support for the lettuce seedling in the system of hydroponic production. Flat graphite electrodes of $1.5 \mathrm{~cm}$ of wide, $10 \mathrm{~cm}$ of longitude with geometric area of $15 \mathrm{~cm}^{2}$ and electroactive area of $12 \mathrm{~cm}^{2}$, approximately, were placed in the Electro-hydroponic cell as anode and cathode, correspondingly (Figure 1).

Four power sources were used in the Electro-hydroponic system; three built at the Center of Investigation in

Table 1. Macronutrients solution applied during the progressive growth of the plant.

\begin{tabular}{ccccc}
\hline COMPOUND & $\begin{array}{c}\text { STEINER 100\% } \\
\mathbf{M g} \cdot \mathbf{L}^{-\mathbf{1}}\end{array}$ & $\begin{array}{c}\text { STEINER 80\% } \\
\mathbf{M g} \cdot \mathbf{L}^{-\mathbf{1}}\end{array}$ & $\begin{array}{c}\text { STEINER 60\% } \\
\mathbf{M g} \cdot \mathbf{L}^{-\mathbf{1}}\end{array}$ & $\begin{array}{c}\text { STEINER 30\% } \\
\mathbf{M g} \cdot \mathbf{L}^{-\mathbf{1}}\end{array}$ \\
\hline $\mathbf{C a}\left(\mathrm{NO}_{3}\right)_{2}$ & 1080 & 864 & 648 & 324 \\
$\mathbf{K N O}_{3}$ & 515 & 412 & 309 & 155 \\
$\mathbf{K}_{2} \mathbf{S O}_{4}$ & 110 & 88 & 66 & 33 \\
$\mathbf{M g S O}_{4}$ & 501 & 401 & 301 & 150 \\
$\mathbf{K H}_{\mathbf{2}} \mathbf{P O}_{4}$ & 103 & 82 & 62 & 31 \\
\hline
\end{tabular}

Table 2. Micronutrients concentration used in the preparation of a standard solution for $60,000 \mathrm{~L}$ of NS.

\begin{tabular}{|c|c|c|}
\hline COMPOUND & $g\left(L^{-1}\right)$ & $\mathrm{g}(\mathrm{Vol} \cdot \mathrm{NS})^{-1}$ \\
\hline $\mathrm{H}_{3} \mathrm{BO}_{3}$ & 0.00288 & 172.8 \\
\hline $\mathrm{MnCl}_{2} \cdot \mathbf{4} \mathrm{H}_{2} \mathrm{O}$ & 0.00181 & 108.6 \\
\hline $\mathrm{ZnSO}_{4} \cdot 7 \mathrm{H}_{2} \mathrm{O}$ & 0.00022 & 13.2 \\
\hline $\mathrm{CuSO}_{4} \cdot 5 \mathrm{H}_{2} \mathrm{O}$ & 0.00018 & 10.8 \\
\hline $\mathrm{H}_{2} \mathrm{MoO}_{4}$ & 0.00002 & 1.2 \\
\hline Fe-EDTA & 0.03787 & \\
\hline
\end{tabular}

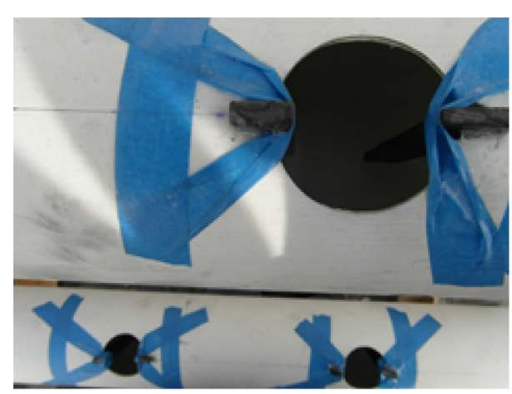

(a)

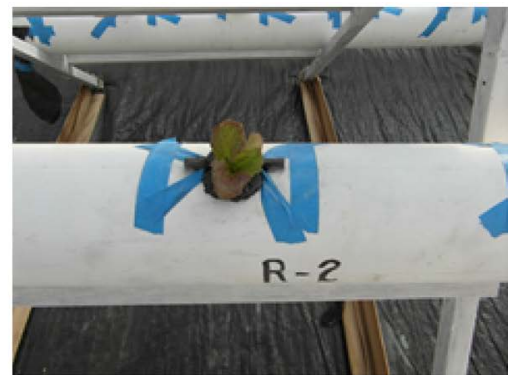

(b)

Figure 1. Electro-hydroponic cell employed in the experiments performed at different applied current intensities. Arrangement of the two electrodes (anode and cathode), with external surface of $1 \mathrm{~cm}$ approximately to interconnect electrically among them (a). Support for the plant (b). 
Engineering and Applied Sciences (CIICAp), by means of an average convertor (CONVER-TLAX) of $120 \mathrm{~V}$ $\mathrm{CA}$ to CD/12V, $5 \mathrm{~A}$, as well as another convertor (LODESTAR) of $12 \mathrm{~V} 3.5 \mathrm{~A}$ and $12-24 \mathrm{~V}, 3.5 \mathrm{~A}$. Voltmeter professional, Steren, model MUL-600.

\subsection{Methods}

The fifty lettuce plants with a similar size were selected and transplanted in the tubes R-1, R-2, R-3 R-4 and R-5 (Electro-hydroponic cell) containing 12 liters of NS at $80 \%$ with $\mathrm{pH}$ of 5.5, the tubes were identified as R-1 which was used as a reference test i.e., at $0 \mathrm{~mA}$, then experiments were also carried out in galvanostatic regime applying different current intensities: R-2, R-3, R-4 and R-5 at $50 \mathrm{~mA}, 37.5 \mathrm{~mA}, 25 \mathrm{~mA}$ and $12.5 \mathrm{~mA}$, respectively. The nutrient solution was changed with a weekly frequency.

After 39 days of growth, the lettuce plants were harvested to measure the foliate area using an equipment LI-COR, Biosciences, model LI-3100C AREA METER. It is worth mentioning that the 39 days correspond to the total time of the experiment i.e., 23 days are associated with the germination and transplant steps, which were carried out in a plastic rigid tray, while 16 days were employed to promote the growth of the plants in the Electro-hydroponic system.

\section{Results and Discussion}

Data of the diameter and foliate area were taken for each plant during the hydroponic process, in an attempt to follow the kinetics of growth of the lettuce subjected at different applied current intensities.

\subsection{Foliate Diameter}

Two values of the foliate diameter were measured for each plant using a ruler. These values were employed to obtain an average diameter. It is important to mention that the diameter measurements were carried out in five plants at 7, 10, 12 and 16 days, as shown in Tables 3-6, respectively. The best results were obtained with the lowest current intensity (12.5 mA), as shown in Figure 2. From these results it is possible to observe that the electric current has an effect on the growth kinetics of the plant, i.e., if it is compared the average foliate diameter of the plant in the absence of current (R1) with that of in the presence of applied current (R5), it is clearly observed that the diameter is increased for the processing times of 7,12 and 16 days. On the other hand, it is also evident that the biggest increase in the diameter to foliate was obtained in the case of the lowest current intensity $(12.5 \mathrm{~mA})$. These results are extremely important, since they show the great impact to use a relatively low current intensity to promote an increase in the growth kinetics of lettuces. The most probable cause of this phenomenon can be related to the next issue: the electric external field could alter the pattern of the metabolism in the plant, as well as the process of passive transport of micro and macro elements through the cationic channels [7].

\subsection{Determination of the Foliate Area}

The foliate area is one of the most important variables in the evaluation of the growth of the plants; the appropriate determination of the same one is fundamental for the correct interpretation of the production processes in a vegetable species. It was measured the area to foliate for each plant at 16 days of growth in the tubes, these measurements were compared with that obtained with the witness (R-1) i.e., with the experiment performed in the absence of electric direct current. In the first set of experiments (labeled as experiment 1), it was evaluated the effect of the current intensity on the foliate area and \% of increment. It is possible to observe in Table 7, that for the case of R-2, when a current intensity of $50 \mathrm{~mA}$ is applied, the foliate area corresponds to $1206 \mathrm{~cm}^{2}$ which reveals a $33.4 \%$ of increment with respect to the control or reference test (R-1). However, it is interesting to observe that when the applied current intensity is decreased to $37.5 \mathrm{~mA}$, the foliate area is increased to $1279 \mathrm{~cm}^{2}$ which reveals an increment of $41.5 \%$ with respect to R1. Finally when the applied current intensity is further decreased to $12.5 \mathrm{~mA}$, the foliate area is also increased to $1494 \mathrm{~cm}^{2}$ which corresponds to an increment of $65.3 \%$ in the growth of the plant with respect to R1. Actually the same experimental conditions were employed in Experiment 2, in order to prove the reproducibility of the effect of the current intensity on the kinetics of growth of lettuce. The results of Experiment 2 are illustrated in Table 8. The results revealed the same effects described in Table 7, i.e., a) when the system is subjected to an applied current intensity, the growth of the lettuce is promoted and b) the kinetics of growth of the plant is favored when the current intensity is decreased from 50 to 
Table 3. Experiment 1, corresponding to the first 7 days after the transplant.

\begin{tabular}{cccccccc}
\hline \multirow{2}{*}{ Tube } & mA & \multicolumn{5}{c}{ FOLIATE DIAMETER $(\mathrm{cm})$} \\
\cline { 3 - 8 } & & Plant 1 & Plant 2 & Plant 3 & Plant 4 & Plant 5 & Average \\
\hline R-1 & - & & 11.25 & 7.65 & 7.00 & 9.75 & 8.90 \\
R-2 & 50.00 & 9.55 & 10.00 & 10.65 & & 9.50 & 9.90 \\
R-3 & 37.50 & 11.25 & 10.00 & 9.50 & 9.00 & & 9.90 \\
R-4 & 25.00 & 7.50 & 8.00 & & 12.00 & 11.00 & 9.60 \\
R-5 & 12.50 & 8.25 & 10.00 & 13.00 & 10.50 & & 10.40 \\
\hline
\end{tabular}

Table 4. Experiment 1, corresponding to 10 days after the transplant.

\begin{tabular}{cccccccc}
\hline \multirow{2}{*}{ Tube } & mA & \multicolumn{5}{c}{ FOLIATE DIAMETER $(\mathrm{cm})$} \\
\cline { 3 - 8 } & & Plant 1 & Plant 2 & Plant 3 & Plant 4 & Plant 5 & Average \\
\hline R-1 & - & & 14.55 & 11.00 & 11.50 & 12.00 & 13.30 \\
R-2 & 50.00 & 11.50 & 12.75 & 14.75 & & 10.50 & 12.40 \\
R-3 & 37.50 & 13.75 & 12.50 & 11.00 & 12.00 & & 12.30 \\
R-4 & 25.00 & 14.00 & 14.00 & & 13.50 & 12.50 & 13.50 \\
R-5 & 12.50 & 12.25 & 13.50 & 15.50 & 12.00 & & 13.30 \\
\hline
\end{tabular}

Table 5. Experiment 1, corresponding to 12 days after the transplant.

\begin{tabular}{cccccccc}
\hline \multirow{2}{*}{ Tube } & mA & \multicolumn{5}{c}{ FOLIATE DIAMETER $(\mathrm{cm})$} \\
\cline { 3 - 8 } & & Plant 1 & Plant 2 & Plant 3 & Plant 4 & Plant 5 & Average \\
\hline R-1 & - & & 15.50 & 11.00 & 11.50 & 13.50 & 12.90 \\
R-2 & 50.00 & 11.50 & 13.50 & 14.75 & & 11.00 & 12.70 \\
R-3 & 37.50 & 15.50 & 13.50 & 13.00 & 12.00 & & 13.50 \\
R-4 & 25.00 & 14.50 & 15.00 & & 13.50 & 12.50 & 13.90 \\
R-5 & 12.50 & 12.50 & 14.00 & 16.00 & 13.90 & & 14.10 \\
\hline
\end{tabular}

Table 6. Experiment 1, corresponding to 16 days after the transplant.

\begin{tabular}{cccccccc}
\hline \multirow{2}{*}{ Tube } & $\mathrm{mA}$ & \multicolumn{5}{c}{ FOLIATE DIAMETER $(\mathrm{cm})$} \\
\cline { 3 - 7 } & & Plant 1 & Plant 2 & Plant 3 & Plant 4 & Plant 5 & Average \\
\hline R-1 & - & & 16.00 & 12.00 & 12.00 & 14.50 & 13.60 \\
R-2 & 50.00 & 12.00 & 15.50 & 15.00 & & 11.00 & 13.50 \\
R-3 & 37.50 & 17.50 & 14.50 & 14.50 & 12.50 & 140 & 14.80 \\
R-4 & 25.00 & 15.50 & 16.00 & & 14.00 & 12.50 & 14.50 \\
R-5 & 12.50 & 13.00 & 15.00 & 17.00 & 15.00 & & 15.00 \\
\hline
\end{tabular}

Table 7. Determination of the foliate area and increment percent in the growth with respect to the reference test (R-1). Experiment 1 .

\begin{tabular}{cccc}
\hline Tube & mA & Foliate area $\left(\mathrm{cm}^{2}\right)$ & \% Increment \\
R-1 & Control & 904.00 & 33.40 \\
R-2 & 50.00 & 1206.00 & 41.50 \\
R-3 & 37.50 & 1279.00 & 38.40 \\
R-4 & 25.00 & 1251.00 & 65.30 \\
R-5 & 12.50 & 1494.00 & \\
\hline
\end{tabular}


$12.5 \mathrm{~mA}$, which indicates that the current intensity required to favor the kinetics of growth of the plants can be optimized. Actually the best results in the growth of the plants were those shown in R-5, which corresponds to the smallest current intensity, i.e. $12.5 \mathrm{~mA}$.

In Figure 2 and Figure 3, which correspond to the Experiment 1, it is observed that the biggest growth of the plants was obtained with the smallest current intensity $(12.5 \mathrm{~mA})$, meanwhile the smallest growth was obtained in the reference or control test ( $\mathrm{R}-1)$ i.e., without an applied current, followed by the test performed at $50 \mathrm{~mA}$ (R-2); this demonstrates the positive effect of the electric field applied to the hydroponic system. In the case of the Experiment 2 (Figure 4), it is observed the same tendency found in the Experiment 1. As mentioned before, the set of tests shown in Experiment 1 and Experiment 2 were carried out with the same conditions of current intensity at the galvanostatic regime, reagent concentration, volume, $\mathrm{pH}$ of the NS and processing time. Experiment 2 was performed in order to prove the reproducibility of this alternative hydroponic system.

Table 8. Determination of the foliate area and increment percent in the growth with respect to the reference test (R-1). Experiment 2.

\begin{tabular}{cccc}
\hline Tube & $\mathrm{mA}$ & Foliate area $\left(\mathrm{cm}^{2}\right)$ & \% Increment \\
\hline R-1 & Control & 1107.00 & 15.70 \\
R-2 & 50.00 & 1281.00 & 30.00 \\
R-3 & 37.50 & 1439.00 & 34.50 \\
R-4 & 25.00 & 1489.00 & 73.20 \\
R-5 & 12.50 & 1917.00 & \\
\hline
\end{tabular}

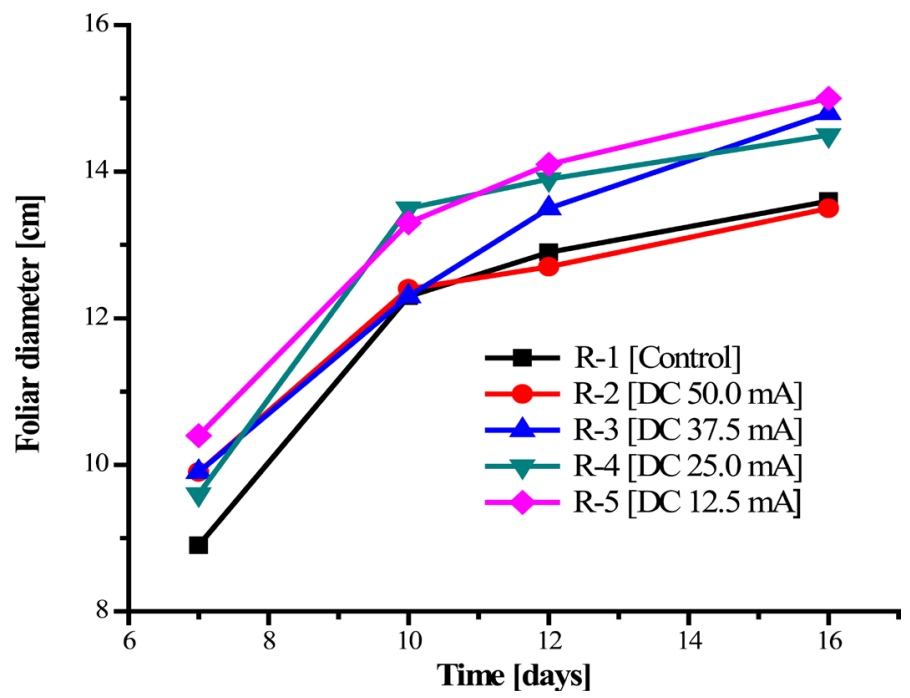

Figure 2. Experiment 1. Growth of plants at different current intensities.

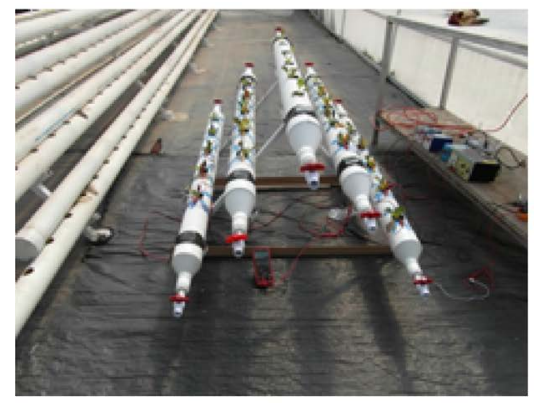

(a)

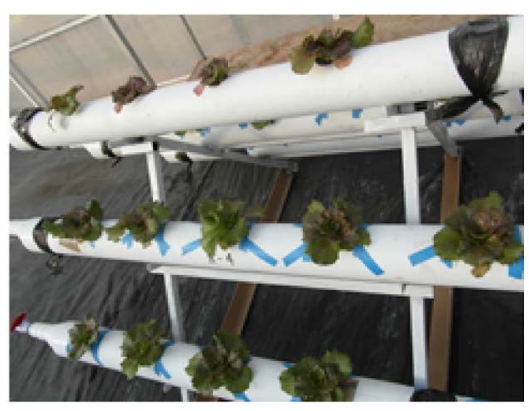

(b)

Figure 3. Experiment 1. System to apply the different intensities of DC to galvanostatic regime (a). Inferior container (R-5), it fed with the smallest intensity of direct current and containsthe plants of more growth (b). 


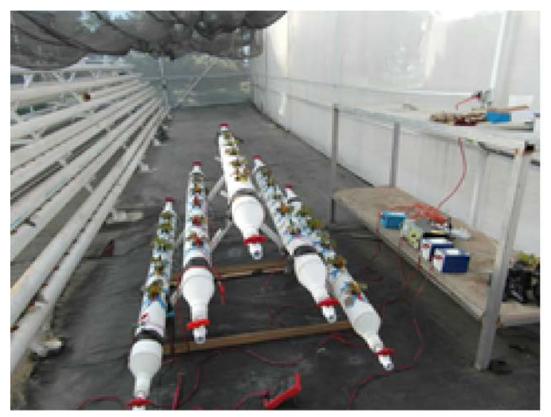

(a)

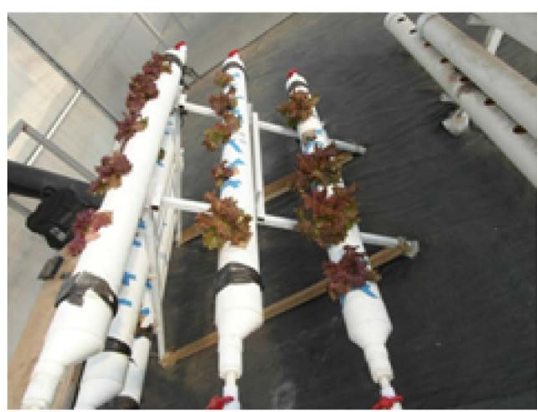

(b)

Figure 4. Experiment 2. System to apply the different intensities of DC to galvanostaticregime (a). Inferior container (R-5), it fed with the smallest intensity of direct current and it contains the plants of more growth (b).

\section{Conclusion}

The generation of an electric field by means of the use of the electric direct current employing a two electrodes conventional system as a hydroponic system, showed that the application of different electric current intensities to the system promotes an increase in the kinetics of growth of the lettuce. Furthermore, the best effect on the kinetics of growth of the plant was obtained with the lowest current intensity, since with this condition, the foliate area was the biggest in comparison to the one expressed by the reference plants. On the basis of the presented results, it is possible to conclude that the use of the electric field in the system of hydroponic culture (Electro-hydroponic system) stimulates the growth of the plants, which reveals the potential of this alternative hydroponic system.

\section{Acknowledgements}

Orlando Fuentes-Castañeda is grateful to CONACYT (Mexico) for the postgraduate scholarship received.

\section{References}

[1] Marfá, O. (2000) Los cultivos sin suelo desde una perspectiva mediterránea. In: Ediciones de Horticultura, S.L., Ed., Recirculación en cultivos sin suelo, Barcelona, 11-20.

[2] Favela-Chávez, E., Preciado-Rangel, P. and Benavides-Mendoza, A. (2006) Manual para la preparación de soluciones nutritivas. Universidad Autónoma Agraria Antonio Narro, Unidad Laguna, Torreón, 7-146.

[3] De Rijck, G. and Schrevens, E. (1998) Cationic Speciation in Nutrient Solutions as a Function of pH. Journal of Plant Nutrition, 21, 861-870. http://dx.doi.org/10.1080/01904169809365449

[4] Amiri, M. and Sattary, N. (2004) Mineral Precipitation in Solution Culture. Acta Horticulturae, 644, 469-471. http://dx.doi.org/10.17660/ActaHortic.2004.644.62

[5] Jaques-Hernández, C. and Hernández-M, J.L. (2005) Valoración productiva de la lechuga hidropónica con la técnica de película de nutrientes (NFT). Transferencia de Tecnología, Centro de Biotecnología Genómica del IPN, Tamaulipas, $11-16$.

[6] Lemström, S. (2008) Electricity in Agriculture and Horticulture. BiblioBazar Reproduction, LLC, Charleston, 1-72.

[7] Bi, R., Schlaak, M., Siefert, E., Lord, R. and Connolly, H. (2010) Alternating Current Electrical Field on Lettuce (Lactuca sativa) Growing in Hydroponic Culture with and without Cadmium Contamination. Journal of Applied Electrochemistry, 40, 1217-1223. http://dx.doi.org/10.1007/s10800-010-0094-X

[8] Myeong, W.S., Sik Yang, D., Kays, S.J., Jun-Hong, K., Ho Woo, J. and Woo Park, K. (2009) Effects of Nutrient Solution Electrical Conductivity and Sulfur, Magnesium, and Phosphorus Concentration on Sesquiterpene Lactones in Hydroponically Grown Lettuce (Lactuca sativa L.). Scientia Horticulturae, 122, 369-374. http://dx.doi.org/10.1016/j.scienta.2009.06.013

[9] Mahmoudi, H., Kaddour, R., Huang, J., Nasri, N., Olfa, B., M’Rah, S., Hannoufa, A., Lachaal, M. and Ouerghi, Z. (2011) Varied Tolerance to $\mathrm{NaCl}$ Salinity Is Related to Biochemical Changes in Two Contrasting Lettuce Genotypes. Acta Physiologiae Plantarum, 33, 1613-1622. http://dx.doi.org/10.1007/s11738-010-0696-2

[10] Carrasco, G. and Izquierdo, J. (1996) Manual Técnico. La empresa hidropónica de mediana escala: La técnica de la solución nutritiva recirculante (NFT). Oficina Regional de la FAO para América Latina y el Caribe, 3-62. 
[11] www.uaem.mx/sites/default/files/facultad-agropecuarias/descargas/2FORMATOPROTOCOLOTESIS.pdf

[12] GRC Agroindustrial, S.A. (2007) Consultado en. http://www.grcagroindustrial.com/grc/index.php?categoryid=8\&p2_articleid=2

[13] Steiner, A.A. (1984) The Universal Nutrient Solution. Sixth International Congress on Soilless Culture, Wageningen, 633-650.

\section{Submit or recommend next manuscript to SCIRP and we will provide best service for you:}

Accepting pre-submission inquiries through Email, Facebook, LinkedIn, Twitter, etc. A wide selection of journals (inclusive of 9 subjects, more than 200 journals)

Providing 24-hour high-quality service

User-friendly online submission system

Fair and swift peer-review system

Efficient typesetting and proofreading procedure

Display of the result of downloads and visits, as well as the number of cited articles

Maximum dissemination of your research work

Submit your manuscript at: http://papersubmission.scirp.org/ 